\title{
Feeding responses of the gastropod Crepidula fornicata to changes in seston concentration
}

\author{
Laurent Barillé*, Bruno Cognie, Peter Beninger, Priscilla Decottignies, Yves Rincé
}

Laboratoire de Biologie Marine, Faculté des Sciences et des Techniques, Université de Nantes, 2 rue de la Houssinière, BP 92208, 44322 Nantes Cedex 3, France

\begin{abstract}
We investigated the response of the suspension-feeding activity of the prosobranch gastropod Crepidula fornicata (L.) to changes in seston abundance and composition, characteristic of the natural particle variability experienced by suspension-feeding organisms as a consequence of tidal resuspension. The experimental conditions were characterized by seston concentrations (12.2 to $196.0 \mathrm{mg} \mathrm{l}^{-1}$ ) inversely related to the organic content of particulate matter (56 to $6 \%$ ). The organic fraction was composed of 2 benthic diatoms, Entomoneis pseudoduplex (Smith) and Nitzschia aurariae (Cholnoky). Inorganic matter was composed of 2 to $3 \mu \mathrm{m}$ diameter kaolinite particles. The functional unit used for determination of ecophysiological responses was a chain of 6 individuals with mean chain dry tissue weight of $1.05 \mathrm{~g}$. The efficiency of particle retention as a function of particle size increased with increasing particle size from 2 to $4 \mu \mathrm{m}$ (equivalent spherical diameter). Above $4 \mu \mathrm{m}$, all particles were cleared from suspension with $100 \%$ efficiency, but retention efficiencies of smaller particles significantly declined with increasing seston loads. A constant clearance rate (CR) was found throughout the seston range, with a mean of $0.76 \pm 0.05 \mathrm{l} \mathrm{h}^{-1} \mathrm{~g}^{-1}$ $( \pm \mathrm{SE})$. Filtration rate increased linearly with seston concentration from a minimum value of $10 \mathrm{mg}$ $\mathrm{h}^{-1} \mathrm{~g}^{-1}$ to a maximum of $42.8 \mathrm{mg} \mathrm{h}^{-1} \mathrm{~g}^{-1}$ at the highest concentration. The total biodeposition rate (sum of pseudofaeces and faeces) followed a similar linear trend, with an increase from 3.8 to $41.6 \mathrm{mg} \mathrm{h}^{-1} \mathrm{~g}^{-1}$ at the highest concentration. Absorption rate was very stable throughout the range of suspended particulate matter concentrations tested with a mean of $4.9 \pm 0.5 \mathrm{mg} \mathrm{h}^{-1} \mathrm{~g}^{-1}( \pm \mathrm{SE})$. It was not possible to ascertain pre-ingestive selection, even though the organic content of biodeposits and diet was very similar. The low retention efficiency of small inorganic particles at high seston loads was the sole mechanism that was clearly identified in this study as counteracting food dilution by inorganic material, through the enrichment of the organic content of filtered matter. The absence of pre-ingestive selection in C. fornicata would increase the physiological significance of this process in turbid environments.
\end{abstract}

KEY WORDS: Crepidula fornicata · Seston load · Retention efficiency · Suspension-feeding behaviour · Particle selection

\section{INTRODUCTION}

Suspension-feeding gastropods occur in a wide range of marine environments. The gill is used in many taxa to capture and transport suspended food particles (Declerck 1995). However, only a few ctenidial filterfeeding gastropods live in turbid marine areas (Fretter \& Graham 1962). Of these, the family Calyptraeidae includes 2 genera, Calyptrae and Crepidula, which can be associated with soft muddy substrates (Fretter \& Graham 1962).

In most species of the protandric hermaphrodite genus Crepidula, adult females are typically sedentary and are strict suspension-feeders, capturing particles in mucus on gill lamella (Werner 1951, Newell \& Kofoed 1977, Chaparro et al. 2002, 2004, Navarro \& Chaparro 
2002), whereas small-sized individuals (juveniles and males) are motile and essentially use their radula to graze the substrate (Chaparro et al. 2002, Navarro \& Chaparro 2002). However, this sexual/functional duality is not evident in the slipper limpet Crepidula fornicata, of which the majority of individuals live in long chains consisting of large females, intersexed individuals and small males (Le Gall 1980), all relying on the suspension-feeding mode. Early juveniles already possess a suspension-feeding ability, unlike other species of the genus (Eyster \& Pechenick 1988).

Crepidula fornicata is an invasive species along western European coasts, particularly in France where many coastal ecosystems have experienced a spectacular increase in the abundance of slipper limpet populations (Blanchard 1995, Thieltges et al. 2004). C. fornicata now colonizes the upper subtidal and intertidal areas of shallow bays characterized by a high concentration of suspended particulate matter (SPM) (Thieltges et al. 2003). In these estuarine habitats, the gastropod is considered as a trophic competitor for cultivated oysters (Walne 1956, but see De Montaudouin et al. 1999, Riera et al. 2002) because of its suspensionfeeding ability, even though functional relationships between rates of feeding and the quantity and quality of available food have never been established.

Studies dealing with the effects of SPM on suspension-feeding bivalves have revealed a complex set of physiological adaptations to seston variability (Hawkins et al. 1996, Urrutia et al. 1996, Barillé et al. 1997; for studies that consider SPM concentrations above $100 \mathrm{mg} \mathrm{l}^{-1}$ see Hawkins et al. 1996, Urrutia et al. 1996, Barillé et al. 1997, Navarro \& Widdows 1997), as well as a morphological plasticity (Barillé et al. 2000). There is no equivalent literature for the suspensionfeeding gastropods, and the feeding behaviour of Crepidula fornicata under conditions of high seston concentration has only been addressed in fragmentary investigations (Johnson 1972, Deslous-Paoli et al. 1987, Shumway et al. 2003). Fretter \& Graham (1962) indicated that high concentrations of suspended matter would clog the gastropod ctenidial filter, and Johnson (1972) showed that slipper limpet growth was affected and clearance rate drastically reduced by increasing silt concentrations. However, Chaparro et al. (2004) recently demonstrated a complex mechanism of pseudofaeces production by Crepidula fecunda, which allows the animal to process particles on the gill continuously at high particle concentration. The demographic success of C. fornicata in turbid macrotidal bays of western Europe suggests that physiological responses may also contribute to (1) maintenance of feeding rates at high SPM and (2) compensation for the dilution of particulate organic matter by an increasing proportion of inorganic resuspended sediment.
Bourgneuf Bay (French Atlantic Coast, $46-47^{\circ} \mathrm{N}$, $\left.1-2^{\circ} \mathrm{W}\right)$ is an invaded shellfish ecosystem characterized by mean annual SPM concentrations of $154 \mathrm{mg} \mathrm{l}^{-1}$ in northern muddy areas and $34 \mathrm{mg} \mathrm{l}^{-1}$ in southern mixed muddy-sandy areas (Haure \& Baud 1995). A stock estimate of Crepidula fornicata, determined for the first time in $40 \mathrm{yr}$ after its occurrence in the bay was first documented by Marteil (1965), yielded a total fresh weight of 55000 tons (P. G. Sauriau \& L. Barillé unpubl. data), in comparison with 48000 tons estimated for the cultivated oyster Crassostrea gigas. Because of the possible implications for the oyster industry, trophic competition between the 2 molluscs was the first negative consequence, among others, of the $C$. fornicata invasion. C. fornicata may also modify the nature and texture of sediment through its biodeposition (Erhold et al. 1998), and can contribute to ecological shifts in the structure of primary producers by changing benthic fluxes (Ragueneau et al. 2002). Our ability to address these concerns would benefit from quantitative measurements of the ecophysiological responses of $C$. fornicata.

The present study investigated the effects of increasing seston concentrations on the feeding physiology of Crepidula fornicata, in order to better understand the mechanisms that allow this suspension-feeding gastropod to prosper in a turbid environment. Seston concentrations (12.2 to $196.0 \mathrm{mg} \mathrm{l}^{-1}$ ) were inversely related to the organic content of particulate matter (56 to $6 \%$ ), which was composed of benthic diatoms isolated from the Bourgneuf Bay mudflat. Seston abundance and composition were consistent with the food variability experienced by suspension-feeding organisms as a consequence of tidal resuspension.

\section{MATERIALS AND METHODS}

Specimen collection. Chains of Crepidula fornicata (L.) were collected in October 2000 in the lower part of the Bourgneuf Bay tidal flat on the French Atlantic coast $\left(47^{\circ} 4.60^{\prime} \mathrm{N}, 2^{\circ} 3.78^{\prime} \mathrm{W}\right)$. Specimens (which, in this area, are attached to pebbles and other shells) were transported immediately to the laboratory, scrubbed of epibionts and maintained in aquaria using oxygenated filtered seawater. They were acclimated for $1 \mathrm{wk}$ to the experimental temperature $\left(15^{\circ} \mathrm{C}\right)$ and salinity (32), and fed with cultured algae (see below). The functional unit used in this study for the determination of the ecophysiological responses was the chain. Indeed, a possible synergetic effect has been suggested among the individuals composing a chain (Le Gall 1980), which has been described as a feeding community (Wilczynski 1958). Moreover, $75 \%$ of $C$. fornicata found in this area are colonial, with a mean of 5.4 individuals per chain 
$(\mathrm{SD}=2.8 ; \mathrm{n}=93)$. Therefore, it was decided to perform the experiment with chains of 6 individuals with a mean chain dry tissue weight of $1.05 \mathrm{~g}(\mathrm{SD}=0.08, \mathrm{n}=8)$.

Algal cultures. Two benthic diatom strains were isolated from a microphytobenthic assemblage sampled in Bourgneuf Bay mudflat: Entomoneis pseudoduplex (Smith) (apical length of the frustule, ALF $=30 \mu \mathrm{m}$ ) and Nitzschia aurariae (Cholnoky) (ALF $=4 \mu \mathrm{m}$ ) (Fig. 1). Microphytobenthic species were selected as food for the experimental diets because Bourgneuf Bay possesses a large mudflat of ca. 2200 ha colonized by benthic diatoms, upon which microalgal assemblages have been mapped (via remote sensing) next to the slipper limpet collection site (Méléder et al. 2003). Microalgae were cultivated in the laboratory and kept in the algal collection of the Laboratoire de Biologie Marine (Faculté des Sciences et des Techniques, University of Nantes) to constitute a diet for Crepidula fornicata. Experimental 501 cultures were obtained using underground seawater supplemented with an enrichment solution (nitrogen, phosphorus and silicon), and maintained at $14^{\circ} \mathrm{C}$ and salinity 28 with a $14 \mathrm{~h}$ photoperiod.

Experimental diets. The particulate organic matter (POM) content of the diet offered to the experimental individuals was a mixture of Nitzschia aurariae at 4000 cells ml ${ }^{-1}$ and Entomoneis pseudoduplex at 2000 cells $\mathrm{ml}^{-1}$. Silt (kaolinite BS1, AGS) was added to the algal mixtures in order to simulate particulate inorganic matter (PIM) and to obtain an increasing range of SPM. Sornin et al. (1988) have shown that kaolinite BS1 is ingested well by oysters compared to other clays. Eight experimental diet conditions were tested (C1 to C8), based on Bourgneuf Bay particulate matter variability as measured by Haure \& Baud (1995). The amount of SPM, PIM and POM in the diet was obtained using the loss-on-ignition method. Water samples were filtered on pre-weighed GF/F filters and dried at $60^{\circ} \mathrm{C}$ for $24 \mathrm{~h}$ for SPM determination; POM was estimated as the filter weight loss after subsequent ignition of samples $\left(450^{\circ} \mathrm{C}\right.$ for $\left.4 \mathrm{~h}\right)$. PIM was deduced from the difference between both measurements. Particle size distributions were determined using a Multisizer II particle counter (Beckman Coulter Electronics) fitted with 50 and $100 \mu \mathrm{m}$ apertures.

Feeding experiments. After a $24 \mathrm{~h}$ acclimation to experimental conditions, chains were placed in a flowthrough experimental system composed of 10 chambers. The chamber design was based upon that of Palmer \& Williams (1980), with 2 levels of baffles. Each chamber measured $25 \times 15 \times 10 \mathrm{~cm}$ and held a volume of 2 l. Prerequisites for using flow-through chambers (influence of chamber geometry, recirculation etc.) were tested according to recommendations by Riisgård (1977, 2001). Milk was used to check that the Crepidula fornicata exhalent flow did not recirculate

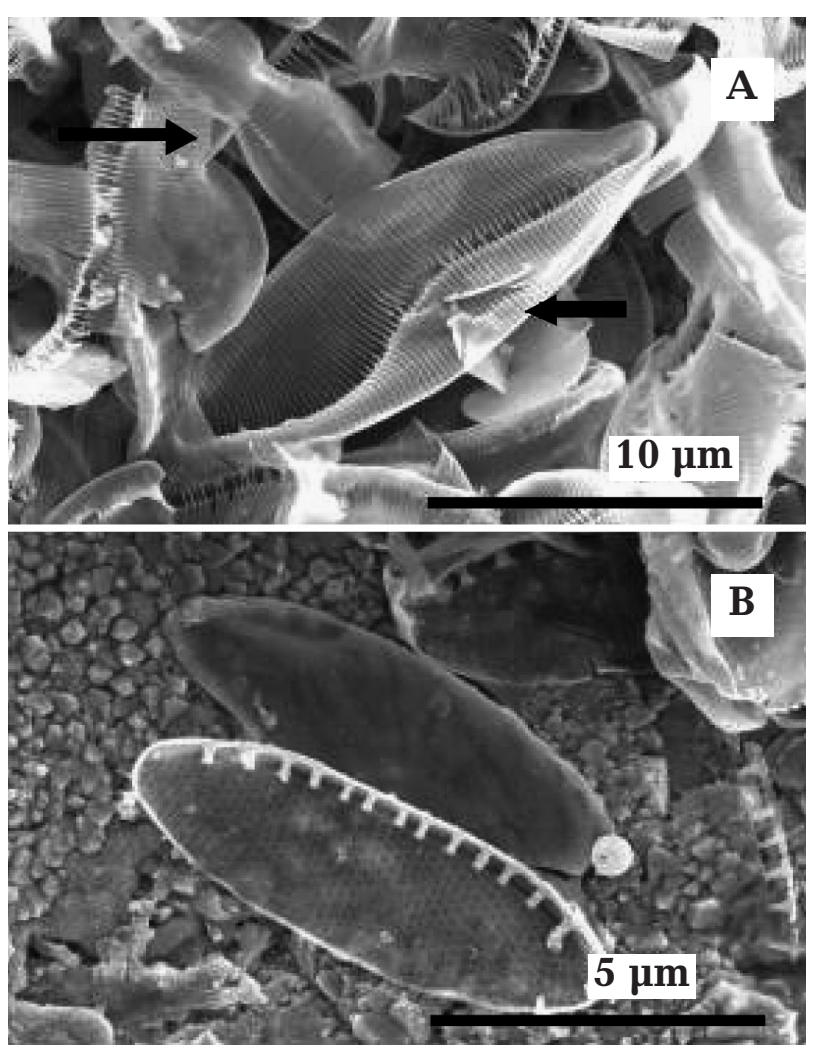

Fig. 1. Benthic microalgae used in experimental diets offered to Crepidula fornicata; scanning electron microscope views of cleaned frustules from cultured strains. (A) Entomoneis pseudoduplex: half-frustules in external (upper left arrow) and internal view (lower right arrow). (B) Nitzschia aurariae: disjoined valves of a frustule, showing fibulae of the keel and punctuations arranged in striae

into the chambers, and that this flow was directed to the outflow of the chambers. The relationship between clearance rate $(\mathrm{CR})$ and flow-through rate was characterized by a marked plateau, at which CR is independent of the flow (Riisgård 1977). A mean flow rate of 41 $\mathrm{h}^{-1}$ was therefore chosen for the experiments. Two chambers containing reconstituted chains with empty shells were used as sedimentation controls (outflow of control chambers was used to represent inflow of chambers with live $C$. fornicata chains adjusted for seston settling). Sampling of ambient water at the chamber outflow began after $1 \mathrm{~h}$ of specimen acclimation. During each set of experimental conditions, which lasted between 3 and 4 h, 3 water samples per individual chamber were analysed with the particle counter. Biodeposits (pseudofaeces could not be separated from faeces), collected with an automatic pipette after $1 \mathrm{~h}$ of biodeposition, were analysed for POM and PIM using the loss-on-ignition method as described above. During the entire experiment, the same 8 chains of C. fornicata were used. 
Determination of feeding processes. Retention efficiency: For the determination of retention efficiencies, particle counts in outflow samples were performed using the particle counter, with coefficients of coincidence $<5 \%$. All particle sizes were expressed as equivalent spherical diameter (ESD). Particle concentrations were estimated for a size range of 1.8 to $15 \mu \mathrm{m}$ ESD. Retention efficiencies $\left(E_{\mathrm{r}}\right)$ were computed for this entire size range as: $E_{\mathrm{r}}(\%)=100 \times$ [(inflow - outflow) $\times$ inflow $\left.^{-1}\right]$, where inflow represents particle concentration in the controls and outflow is particle concentration in the troughs containing the animals. Details of $E_{\mathrm{r}}$ calculations are given in Barillé et al. (1993).

Clearance rate: $E_{\mathrm{r}}$ data were considered to represent a possible underestimation of $\mathrm{CR}$, owing to small particles passing through the interfilamentar spaces and being released into chambers with the exhalent flow. To determine this potential underestimation, 3 retention ratios (inflow - outflow $\times$ inflow $^{-1}$ ) were calculated from particle counts based on particles in the 2-15, 3-15 and 6-15 $\mu \mathrm{m}$ size ranges (ESD). These ranges were chosen because the greatest differences in CR estimations were observed with 2 to $3 \mu \mathrm{m}$ particles. CRs calculated within the 2-15 and 3-15 $\mu \mathrm{m}$ size ranges were compared with the CR calculated with particles above a threshold that ensured that all were cleared with $100 \%$ efficiency, i.e. in the $6-15 \mu \mathrm{m}$ size range (Jørgensen et al. 1984). Given the mean flow in an individual chamber, $\mathrm{CR}\left(\mathrm{l} \mathrm{h}^{-1}\right)$ was calculated as [(inflow - outflow $) \times$ inflow $\left.^{-1}\right] \times$ flow rate. The number of individuals per chain with shells tightly closed was estimated for each set of conditions on 5 randomly chosen chains.

Filtration, biodeposition and absorption rates: Filtration rate $\left(\mathrm{FR}_{i} \mathrm{mg} \mathrm{h}^{-1}\right)$, which represents the mass of particles filtered per unit of time, was calculated as [(inflow - outflow)] $\times$ flow rate, where inflow represents SPM concentration in the controls and outflow the SPM concentration in chambers containing the animals. Organic filtration rate $\left(\mathrm{OFR}_{i} \mathrm{mg}_{\mathrm{POM} \mathrm{h}} \mathrm{P}^{-1}\right)$ was calculated using POM concentrations in the controls and outflow. The total biodeposition rate $\left(\mathrm{TBR}_{;} \mathrm{mg} \mathrm{h}^{-1}\right)$ was represented by total particulate matter biodeposited (sum of pseudofaeces and faeces) per unit of time.

Absorption rate of organic matter $\left(\mathrm{AR}_{i} \mathrm{mg} \mathrm{POM} \mathrm{h}^{-1}\right)$ was estimated as the difference between FR and TBR, assuming that the inorganic material filtered was equal to the inorganic material rejected in the biodeposits (Iglesias et al. 1998).

Weight standardization. Because of the limited variability among experimental chains ( $\mathrm{SD}=0.08 \mathrm{~g}$ dry tissue weight) and a mean weight $\approx 1 \mathrm{~g}$, the standardization did not significantly modify the feeding processes expressed per chain. However, it was decided to rigorously apply a standardization to a chain of $1 \mathrm{~g}$ dry tissue weight using the allometric exponent of 0.56 determined by Navarro \& Chaparro (2002) for Crepidula fecunda. To our knowledge, such a parameter does not exist in the literature for $C$. fornicata. Standardization was obtained with the following equation (Bayne et al. 1987):

$$
Y_{\mathrm{s}}=\left(1 / W_{\mathrm{ex}}\right)^{b} Y_{\mathrm{ex}}
$$

where $Y_{\mathrm{s}}$ represents the value for the standard chain, $Y_{\text {ex }}$ the experimental value, $b$ the allometric exponent and $W_{\text {ex }}$ the experimental weight.

Statistical analysis. After verification of underlying assumptions, feeding processes were compared using a 1-way repeated measures ANOVA, as the same chains were tested for the 8 experimental conditions (Sokal \& Rohlf 1995).

\section{RESULTS}

\section{Seston characterization}

Experimental seston concentrations (SPM) varied between 12.2 and $196 \mathrm{mg} \mathrm{l}^{-1}$ and POM varied between 6.8 and $23.2 \mathrm{mg} \mathrm{l}^{-1}$ (Table 1). The organic content of the diets (Table 1) decreased with increasing seston concentration, from $56 \%$ at the lowest seston load to $6 \%$ at the highest. The organic content values obtained in this study are consistent with in situ data measured by Haure \& Baud (1995) in Bourgneuf Bay (Fig. 2). The size distribution of particles for the first 4 experimental conditions (C1 to $\mathrm{C} 4$ ) showed 3 modes. The first, at approximately 2 to $3 \mu \mathrm{m}$ ESD, was due to inorganic particles, while the other two corresponded to the 2 benthic microalgae, with Nitzschia aurariae at $3 \mu \mathrm{m}$ ESD and Entomoneis pseudoduplex at 9 to $10 \mu \mathrm{m}$

Table 1. Characteristics of experimental diets (C1-C8) supplied to Crepidula fornicata. Data are means of 4 replicates per condition. SPM: suspended particulate matter $\left(\mathrm{mg} \mathrm{l}^{-1}\right)$; POM: particulate organic matter $\left(\mathrm{mg} \mathrm{l}^{-1}\right)$

\begin{tabular}{|lrrrrc|}
\hline \multirow{2}{*}{ Diet } & \multicolumn{2}{c}{ SPM } & \multicolumn{2}{c|}{ POM } & \multirow{2}{*}{ Organic } \\
& Mean & SD & Mean & SD & content (\%) \\
\hline C1 & 12.2 & 0.8 & 6.8 & 0.6 & 56 \\
C2 & 30.2 & 9.3 & 11.2 & 1.1 & 37 \\
C3 & 65.6 & 4.0 & 20.8 & 1.7 & 32 \\
C4 & 75.6 & 11.3 & 23.2 & 4.5 & 31 \\
C5 & 100.0 & 13.6 & 10.0 & 1.7 & 10 \\
C6 & 106.0 & 1.7 & 8.2 & 1.4 & 8 \\
C7 & 163.3 & 1.8 & 13.7 & 3.2 & 8 \\
C8 & 196.0 & 16.0 & 12.3 & 0.4 & 6 \\
\hline
\end{tabular}


ESD (Fig. 3A). However, with increasing seston loads (from conditions $\mathrm{C} 5$ to $\mathrm{C} 8$ ), the modes of the two microalgae could no longer be detected and the distributions became unimodal, dominated by inorganic matter (Fig. 3B).

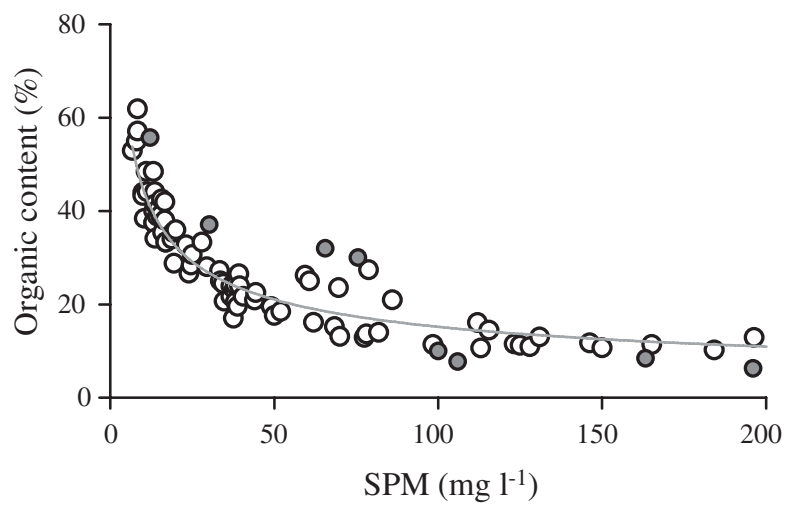

Fig. 2. Relationship between organic content of seston and suspended particulate matter (SPM) concentration. O: experimental data from this study; O: in situ data collected by Haure \& Baud (1995) in Bourgneuf Bay. The following power function was fitted to their data: organic content $=132.8 \mathrm{SPM}^{-0.471}$

$$
\left(r^{2}=0.89\right)
$$

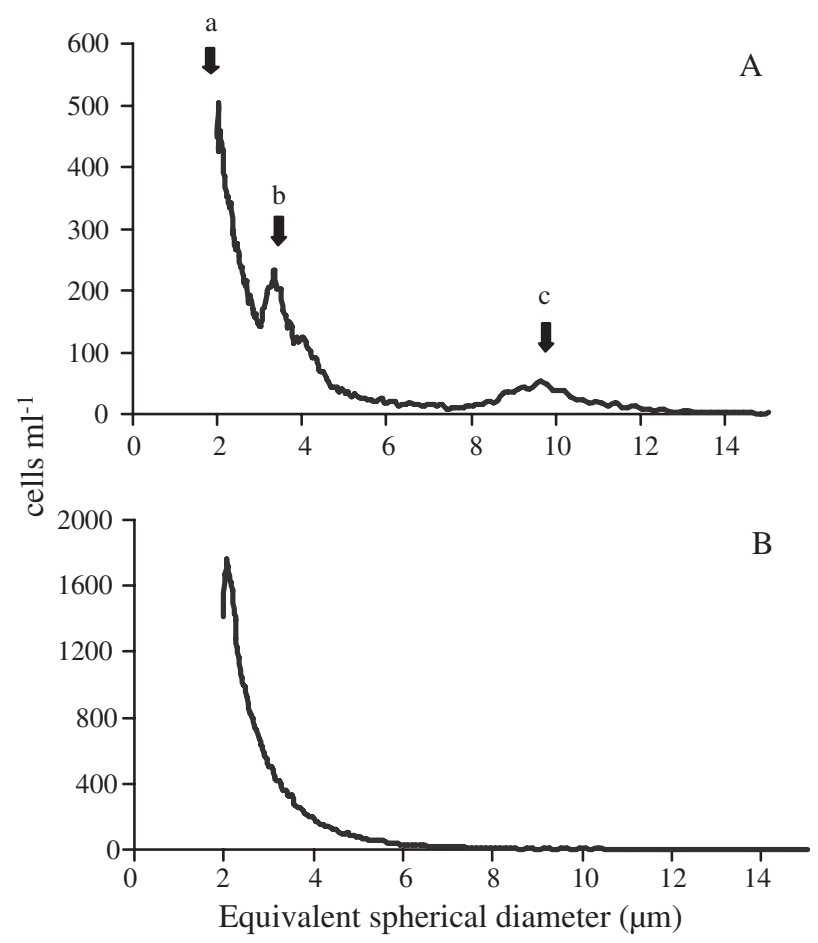

Fig. 3. Particle size distribution of experimental diets. Spectra of diets (A) C1 (SPM = $12.2 \mathrm{mg} \mathrm{l}^{-1}$ ) and (B) C5 (SPM = $100.0 \mathrm{mg} \mathrm{l}^{-1}$ ) shown to illustrate food dilution by increasing concentrations of inorganic particles; $\mathrm{a}=$ kaolinite particles; $\mathrm{b}=$ Nitzschia aurariae $\mathrm{c}=$ Entomoneis pseudoduplex

\section{Physiological responses}

Retention efficiency

Particle $E_{\mathrm{r}}$ as a function of particle size increased with increasing particle size from 2 to $4 \mu \mathrm{m}$ ESD (Fig. 4); $4 \mu \mathrm{m}$ represented the threshold above which all particles were cleared from suspension with $100 \%$ efficiency for all seston concentrations. However, for particles smaller than $4 \mu \mathrm{m}$ ESD, $E_{\mathrm{r}}$ significantly declined (ANOVA, p < 0.01) with increasing seston loads. For SPM concentrations between 100 and $196 \mathrm{mg} \mathrm{l}^{-1}, E_{\mathrm{r}}$ of $2.2 \mu \mathrm{m}$ ESD particles was close to $0 \%$; in contrast, retention was $67 \%$ for SPM concentrations between 12.2 and $30.2 \mathrm{mg} \mathrm{l}^{-1}$.

\section{Clearance rate}

The calculation of CR $\left(\mathrm{l} \mathrm{h}^{-1} \mathrm{~g}^{-1}\right)$ can be biased by small particles not retained by the feeding structures of Crepidula fornicata, and this bias increased with increasing seston concentrations (Fig. 5A). CRs were lowest when calculated with particles in the size range 2-15 $\mu \mathrm{m}$ ESD, i.e. taking into account the full size spectrum. The values increased with the size range 3-15 $\mu \mathrm{m}$ ESD, but were still consistently lower than CRs calculated with particles retained with $100 \%$ efficiency, in the $6-15 \mu \mathrm{m}$ ESD size range. With the first 2 calculations $(2-15$ and $3-15 \mu \mathrm{m})$, the results indicated a significant decline in $\mathrm{CR}$ with increasing seston concentration (ANOVA, p < 0.05); in contrast, there was no significant difference for CR calculated with particles in the range 6-15 $\mu \mathrm{m}$ ESD (Fig. 5B; ANOVA, $p=0.23$ ). For the latter particle range and

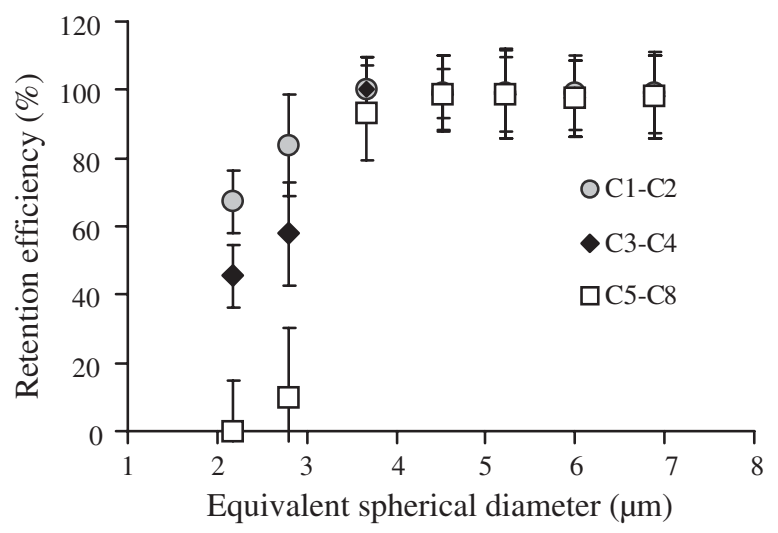

Fig. 4. Crepidula fornicata. Retention efficiency at increasing SPM concentrations. Data obtained by grouping conditions C1 and C2 (12.2 to $30.2 \mathrm{mg} \mathrm{l}^{-1}$ ), C3 and C4 (65.6 to $75.6 \mathrm{mg} \mathrm{l}^{-1}$ ) and $\mathrm{C} 5$ and C8 (100.0 to $196.0 \mathrm{mg} \mathrm{l}^{-1}$ ) (for further details see Table 1). Means presented with $95 \%$ confidence intervals 


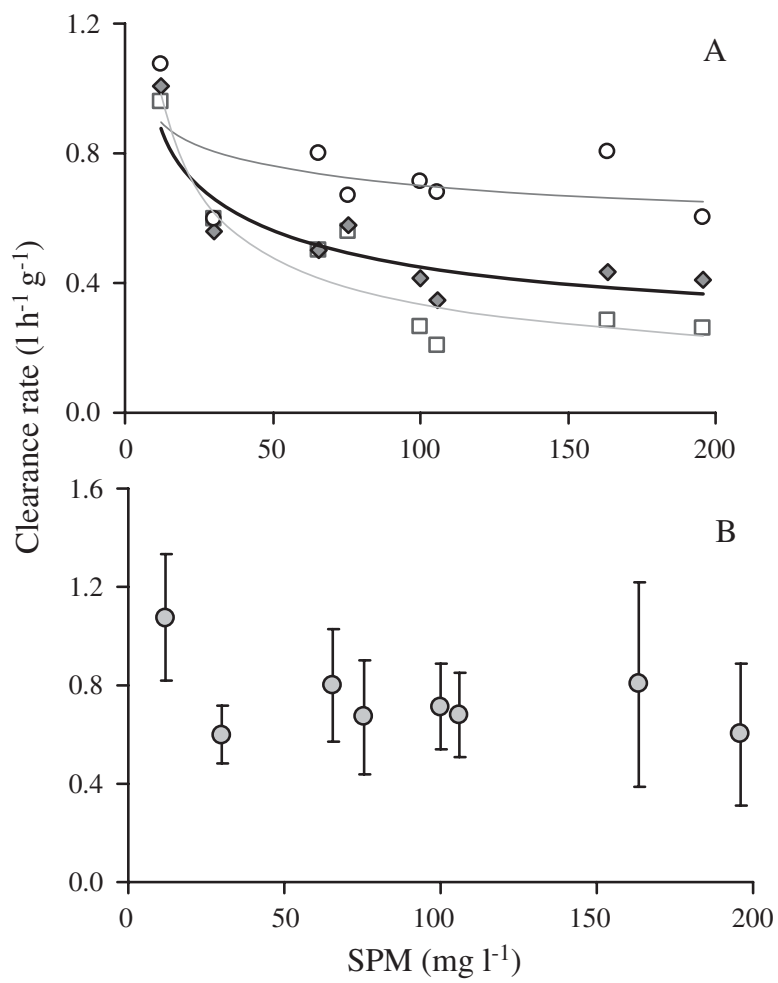

Fig. 5. Crepidula fornicata. Clearance rates (CR) at increasing SPM concentrations. (A) CRs calculated with 3 particle size ranges: $2-15 \mu \mathrm{m}(\square), 3-15 \mu \mathrm{m}(\diamond), 6-15 \mu \mathrm{m}(0)$; power curves adjusted to data for better visual discrimination. (B) Mean CRs calculated for 6-15 $\mathrm{mm}$ size range with 95\% confidence intervals

SPM concentrations of 163.3 and $196.0 \mathrm{mg} \mathrm{l}^{-1}$, CRs were $0.91 \mathrm{l} \mathrm{h}^{-1} \mathrm{~g}^{-1}(\mathrm{SE}=0.24)$ and $0.68 \mathrm{l} \mathrm{h}^{-1} \mathrm{~g}^{-1}(\mathrm{SE}=$ $0.16)$, respectively, and not significantly lower than CRs calculated for SPM concentrations ranging from 12.2 to $106.0 \mathrm{mg} \mathrm{l}^{-1}$ (ANOVA, $\mathrm{p}=0.11$ ). For all conditions combined, the mean $\mathrm{CR}$ for a chain of $C$. fornicata of 6 individuals was $0.76 \pm 0.05 \mathrm{l} \mathrm{h}^{-1} \mathrm{~g}^{-1}( \pm \mathrm{SE})$. On average, it was estimated that at least 1 individual per chain was not filtering, as based on visual observations during the experiments.

\section{Filtration rate}

FR $\left(\mathrm{mg} \mathrm{h}^{-1} \mathrm{~g}^{-1}\right.$; organic + inorganic matter) of Crepidula fornicata linearly increased with SPM concentration (Fig. 6A) to a maximum of $42.8 \mathrm{mg} \mathrm{h}^{-1} \mathrm{~g}^{-1}$ at the highest concentration (196.0 $\left.\mathrm{mg} \mathrm{l}^{-1}\right)$. A significant linear regression described the relationship between FR and SPM ( $\mathrm{p}<0.05$, Table 2). Organic filtration rate (OFR, mg POM $\mathrm{h}^{-1}$ ) followed a constant trend (Fig. 6A), with a mean OFR of $7.5 \pm 0.7 \mathrm{mg} \mathrm{POM} \mathrm{h}^{-1} \mathrm{~g}^{-1}$ $( \pm \mathrm{SE})$.
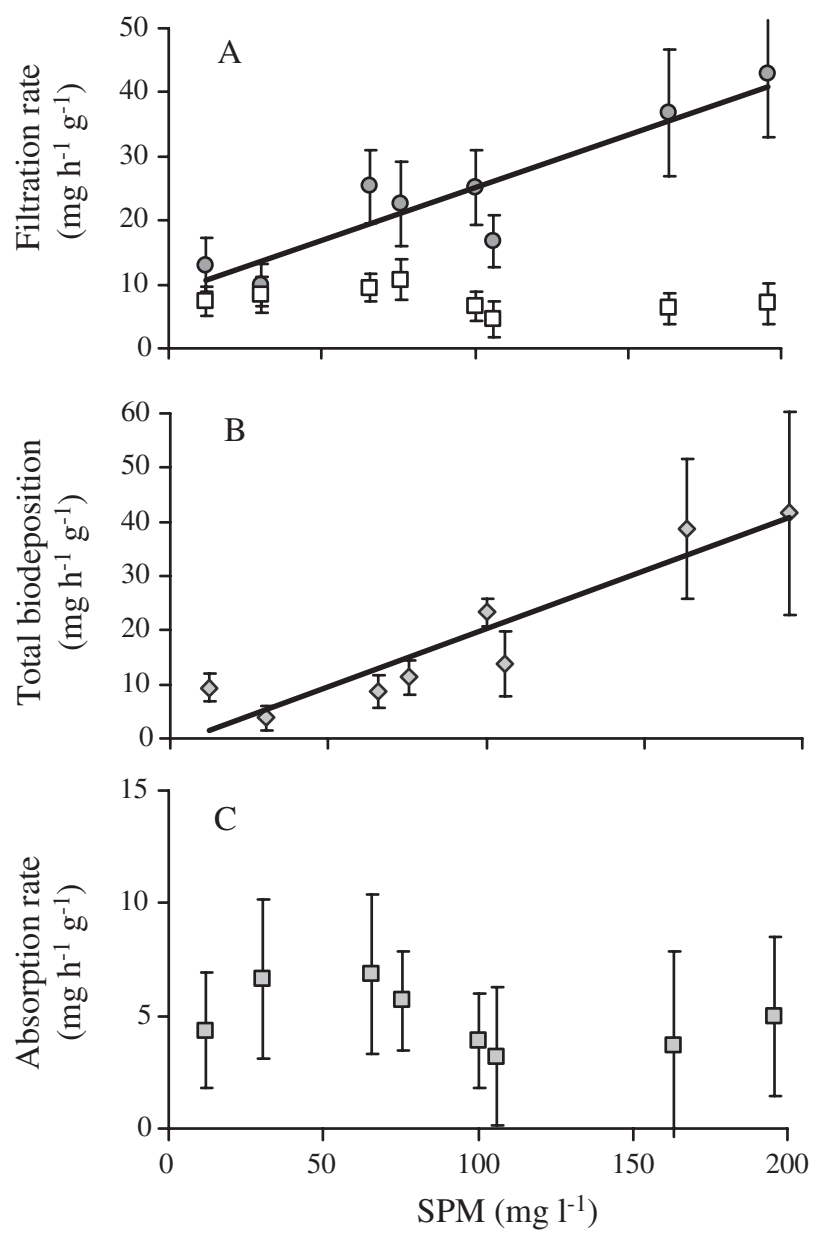

Fig. 6. Crepidula fornicata. Rates of (A) filtration (O) (mg of TPM h $\mathrm{h}^{-1} \mathrm{~g}^{-1}$ ) and organic filtration ( $\square$ ) (mg of organic matter $\mathrm{h}^{-1} \mathrm{~g}^{-1}$ ), (B) total biodeposition (pseudofaeces + faeces, $\mathrm{mg}$ of $\mathrm{SPM} \mathrm{h}^{-1} \mathrm{~g}^{-1}$ ), and (C) absorption (mg of POM h $\mathrm{h}^{-1} \mathrm{~g}^{-1}$ ), as a function of SPM concentrations. Means presented with $95 \%$ confidence intervals. Linear regression equations and significance detailed in Table 2

\section{Total biodeposition rate}

Biodeposition was estimated by the sum of pseudofaeces and faeces production combined and expressed as TBR (mg h ${ }^{-1} \mathrm{~g}^{-1}$; organic + inorganic matter). A significant linear regression described the relationship between TBR and SPM ( $p<0.05$; Fig. 6B, Table 2). The minimum TBR was $3.8 \mathrm{mg} \mathrm{h}^{-1} \mathrm{~g}^{-1}$ and increased to $41.6 \mathrm{mg} \mathrm{h}^{-1} \mathrm{~g}^{-1}$ at the highest concentration $(196.0 \mathrm{mg}$ $\mathrm{l}^{-1}$ ). Above $150 \mathrm{mg} \mathrm{l}^{-1}$, the variability of this ecophysiological response was greater than at the lower seston load, as shown by the increase in the range of confidence intervals of means. A significant linear regression described the relationship between TBR and SPM $(p<0.05$, Table 2$)$. This regression was used to estimate the threshold of biodeposit production at $5.5 \mathrm{mg}$ $\mathrm{l}^{-1} \mathrm{SPM}$, by resolving the linear regression equation for 
Table 2. Linear regression equations describing relation of best fit between SPM (mg l${ }^{-1}$; independent variable) and Crepidula fornicata ecophysiological responses: filtration rate $\left(\mathrm{FR}_{i} \mathrm{mg} \mathrm{h}^{-1} \mathrm{~g}^{-1}\right.$ ) and total biodeposition rate $\left(\mathrm{TBR}_{i} \mathrm{mg} \mathrm{h}^{-1} \mathrm{~g}^{-1}\right)$. Significance of regressions is $\mathrm{p}<0.05$ associated with the Fischer significance test

\begin{tabular}{|lccc|}
\hline $\begin{array}{l}\text { Dependent } \\
\text { variable }\end{array}$ & $\mathrm{a}$ & $\mathrm{b}$ & $\mathrm{b}$ \\
\cline { 2 - 4 } & & 8.572 & $\mathrm{r}^{2}$ \\
\hline FR & 0.1652 & -1.168 & 0.83 \\
TBR & 0.2135 & 0.86 \\
\hline
\end{tabular}

$\mathrm{TBR}=0$. The organic content of the biodeposits was compared to the composition of the diets (Fig. 7). The overall comparison revealed that the difference between the measurements and theoretical values on the isometric line $x=y$ (organic content of the biodeposits equals organic content of the diets) was not significant (Wilcoxon signed ranks test, $\mathrm{p}=0.17$ ).

\section{Absorption rate}

Food AR (mg organic matter $\mathrm{h}^{-1} \mathrm{~g}^{-1}$ ) was constant within the range of SPM concentrations tested, from 12.2 to $196 \mathrm{mg} \mathrm{l}^{-1}$ (Fig. 6C). A linear regression fitted to the data between AR and SPM showed that the slope of the regression was not significantly different from 0 ( $p=0.45)$. For all conditions combined, the mean AR was $4.9 \pm 0.5 \mathrm{mg} \mathrm{h}^{-1} \mathrm{~g}^{-1}( \pm \mathrm{SE})$.

\section{DISCUSSION}

Suspension-feeders inhabiting shallow, soft-bottom macrotidal marine systems face high levels of SPM concentrations and a dilution of food particles by resuspended inorganic material (Widdows et al. 1979). The seston conditions used in the present study reproduced this dilution effect as illustrated by the close correspondence between the data and field measurements (Fig. 2), which showed a negative relationship between organic content and SPM. Such a relationship, represented by a decreasing power function, is typical of tidal resuspension in temperate and tropical waters (Hawkins et al. 1996, Barillé et al. 1997, Navarro \& Widdows 1997, Hawkins et al. 1998).

In the range of SPM tested, the ecophysiological responses of Crepidula fornicata were not affected by increasing seston concentrations. This result contrasts with the finding of Johnson (1972) on the same species, who showed a negative effect of silt on $\mathrm{CR}$, with the sharpest reduction occurring from 140 to $200 \mathrm{mg} \mathrm{l}^{-1}$. This author, like Fretter \& Graham (1962) earlier, sug-

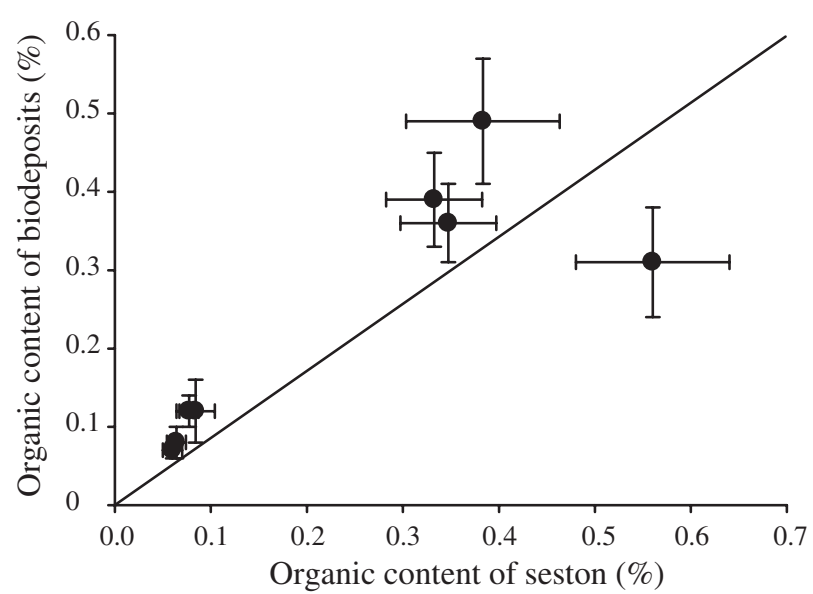

Fig. 7. Crepidula fornicata. Organic content of biodeposits (pseudofaeces + faeces) compared to composition of diets $($ means $\pm \mathrm{SD})$

gested a clogging of the particle-processing mechanism. In the present study, CR did not decrease when SPM concentrations exceeded $140 \mathrm{mg} \mathrm{l}^{-1}$, with no significant differences throughout the SPM range. However, we showed that CR could be underestimated by the low retention efficiency of small particles, with an increasing bias at high seston loads, which could give the erroneous impression that $C$. fornicata can adjust to feeding conditions by reducing its CR (Fig. 5A). We suspect that methodological differences may explain this divergence, because Johnson applied the clearance method (Coughlan 1969) using silt concentration in the CR equation, probably not taking into account the inefficiently retained particles in suspension in his static system (Williams 1982). However, Shumway et al. (2003) reported a significant effect of clay particulates on C. fornicata CRs but at a much higher concentration (10000 $\left.\mathrm{mg} \mathrm{l}^{-1}\right)$.

The efficiency of particle retention as a function of particle size was lower than that estimated by Jørgensen et al. (1984), who reported that Crepidula fornicata was able to retain particles down to $2 \mu \mathrm{m}$ with a maximal efficiency. In the present study, this threshold was only found for particles above $4 \mu \mathrm{m}$, and at the highest seston loads $C$. fornicata was almost unable to retain 2 to $3 \mu \mathrm{m}$ particles. A striking result is this negative influence of SPM on the gastropod retention efficiencies for small particles, a phenomenon that has been documented in bivalves (Palmer \& Williams 1980, Cranford \& Gordon 1992, Barillé et al. 1993, Hawkins et al. 1998). Whether this process is a physiological regulation or a passive mechanism based solely on the physical properties of the particles (La Barbera 1978) is unknown, but the consequence is an enrichment in organic content of filtered particles on the gill. 
Published values of CRs of adult Crepidula fornicata have all been obtained with isolated individuals, sometimes separated from a chain (Johnson 1972, Newell \& Kofoed 1977, Jørgensen et al. 1984, Navarro \& Chaparro 2002, Shumway et al. 2003). The mean CR of $0.76 \mathrm{l} \mathrm{h}^{-1} \mathrm{~g}^{-1}$ calculated in this study for chains of 6 individuals can be compared with those obtained in previous studies with individuals, by applying an allometric standardization. In fact, it is very similar to the result reported by Newell \& Kofoed (1977) $\left(250 \mathrm{ml} \mathrm{h}^{-1}\right.$ at $15^{\circ} \mathrm{C}$ for a $160 \mathrm{mg}$ specimen), which corresponds to a value of $0.71 \mathrm{~h}^{-1} \mathrm{~g}^{-1}$. It is also consistent with the finding of Navarro \& Chaparro (2002) for C. fecunda, which is equivalent to a CR of $0.44 \mathrm{l} \mathrm{h}^{-1} \mathrm{~g}^{-1}$ when their allometric relationship is applied to a standard dry weight of $1 \mathrm{~g}$. Although significantly lower, our result cannot be compared with the data reported by Shumway et al. (2003) (CRs $>21 \mathrm{~h}^{-1} \mathrm{~g}^{-1}$ for a similar SPM range), who calculated a weight-specific CR without allometric standardization. It is also 16 times lower than the value of $0.66 \mathrm{l} \mathrm{h}^{-1}$ obtained by Jørgensen et al. (1984) with algal cell diets for a $132 \mathrm{mg}$ specimen. Testing the feeding community concept (CR of a chain > sum of individual CRs) was beyond the scope of this study, but the choice of studying a chain's feeding responses was more realistic due to the predominance of colonies in the population. However, as already mentioned, the entire chain was seldom fully active, with on average approximately 1 individual out of 6 not filtering.

As a consequence of the CR that was constant with increasing seston concentration, the amount of suspended material retained on the gills increased in proportion to particulate matter availability, followed by a linear increase in biodeposition. This linear relationship between filtration rate and seston concentration indicates that gastropods are still processing large amounts of particles at SPM $>100 \mathrm{mg} \mathrm{l}^{-1}$, in spite of the decreasing food quality (organic content $\leq 10 \%$ ). Such functional feeding responses have been described in suspension-feeding bivalves where FR increases up to a threshold, above which particle-processing constraints on the gills and labial palps have been suggested to account for a decline at higher seston concentrations (Widdows et al. 1979, Barillé et al. 1997, Navarro \& Widdows 1997, Bayne 2002). This threshold fluctuates over a wide range of SPM ca. 100 to $1000 \mathrm{mg}$ $\mathrm{l}^{-1}$ according to species and habitat. If such a threshold exists in Crepidula fornicata, it would occur at SPM concentrations higher than the ca. $200 \mathrm{mg} \mathrm{l}^{-1}$ used in this study.

High FR in bivalves of turbid habitats is considered as a way to maximize food intake, because the filtered material is subjected to pre-ingestive selection (Kiørboe \& Møhlenberg 1981, Newell \& Jordan 1983,
Hawkins et al. 1996, Ward et al. 1998). An equivalent mechanism has never been demonstrated in suspension-feeding gastropods, even though it has been previously suggested for the genus Crepidula (Werner 1951, Navarro \& Chaparro 2002). Moreover, Declerck (1995) indicated that the absence of a sorting mechanism prior to ingestion was a distinction between bivalves and gastropods. In this study, the choice of a chain as a functional unit did not permit the 2 types of biodeposits to be distinguished. Pseudofaeces and faeces were essentially voided in the same area from the anterior shell margin on the right side of an animal, and the rejections of all individuals composing a chain were mixed together. It was therefore not possible to unequivocally establish or reject the hypothesis of preingestive particle selection. Nevertheless, the similarity between the organic content of biodeposits and diet is intriguing: firstly, because qualitative observations revealed that most of the rejected matter was made of pseudofaeces; secondly, because faeces resulting from a digestive process probably did not contribute to an increase in the organic content of biodeposits.

If we hypothesize that pre-ingestive selection is absent in Crepidula fornicata, this would signify a considerable disadvantage for an organism constantly facing food dilution in a resuspended tidal environment and would not seem compatible with high filtration rates. The elevated organic content of biodeposits may, however, result from a significant contribution of mucous secretion in pseudofaeces (Chaparro et al. 2004). Further investigations are required to elucidate pre-ingestive particle processing mechanisms in $C$. fornicata (in progress) and suspension-feeding gastropods in general. The reduction in retention efficiencies of small inorganic particles at high seston loads was the sole mechanism clearly identified in this study as counteracting food dilution by the enrichment of organic content of filtered matter. If conclusively demonstrated, the absence of pre-ingestive selection in C. fornicata would increase the physiological significance of this process in turbid environments.

Acknowledgements. We are grateful to P. Rosa and R. Duquenne for their assistance. This study was financially supported by the Région des Pays de la Loire, through the SMIDAP (Syndicat mixte pour le développement de l'aquaculture en Pays de la Loire).

\section{LITERATURE CITED}

Barillé L, Prou J, Héral M, Bougrier S (1993) No influence of food quality, but ration-dependent retention efficiencies in the Japanese oyster Crassostrea gigas. J Exp Mar Biol Ecol 171:91-106

Barillé L, Prou J, Héral M, Razet D (1997) Effects of high natural seston concentration on the feeding, selection and 
absorption of the oyster Crassostrea gigas. J Exp Mar Biol Ecol 212:149-172

Barillé L, Haure J, Cognie B, Leroy A (2000) Variations in pallial organs and eulatero-frontal cirri in response to high particulate matter concentrations in the oyster Crassostrea gigas. Can J Fish Aquat Sci 57:837-843

Bayne BL (2002) A physiological comparison between Pacific oysters Crassostrea gigas and Sydney Rock oysters Saccostrea glomerata: food, feeding and growth in a shared estuarine habitat. Mar Ecol Prog Ser 232:163-178

Bayne BL, Hawkins AJS, Navarro E (1987) Feeding and digestion by the mussel Mytilus edulis in mixtures of silt and algal cells at low concentrations. J Exp Mar Biol Ecol 111:1-22

Blanchard M (1995) Origine et état de la population de Crepidula fornicata (Gastropoda prosobranchia) sur le littoral français. Haliotis 24:75-86

Chaparro OR, Thompson RJ, Pereda SV (2002) Feeding mechanisms in the gastropod Crepidula fecunda. Mar Ecol Prog Ser 234:171-181

Chaparro OR, Segura CJ, Navarro JM, Thompson RJ (2004) The effect of food supply on feeding strategy in sessile female gastropods Crepidula fecunda. Mar Biol 144:79-87

Coughlan J (1969) The estimation of filtering rate from the clearance of suspensions. Mar Biol 2:356-358

Cranford PJ, Gordon DC (1992) The influence of dilute clay suspensions on sea scallop (Placopecten magellanicus) feeding activity and tissue growth. Neth J Sea Res 30: 107-120

Declerck CH (1995) The evolution of suspension feeding in gastropods. Biol Rev 70:549-569

De Montaudouin X, Audemard C, Labourg PJ (1999) Does the slipper limpet (Crepidula fornicata, L.) impair oyster growth and zoobenthos biodiversity? A revisited hypothesis. J Exp Mar Biol Ecol 235:105-124

Deslous-Paoli JM, Sornin JM, Héral M (1987) Variations saisonnières in situ de la production de biodépôts de trois mollusques estuariens, Mytilus edulis, Crassostrea gigas, Crepidula fornicata. Haliotis 16:233-245

Erhold A, Blanchard M, Auffret JP, Garlan T (1998) Conséquences de la prolifération de la crépidule, Crepidula fornicata sur l'évolution sédimentaire de la baie du Mont Saint Michel, Manche, France. CR Acad Sci Paris Earth Planet Sci 327:583-588

Eyster LS, Pechenik JA (1988) Comparison of growth, respiration, and feeding of juvenile Crepidula fornicata (L.) following natural or KCL-triggered metamorphosis. J Exp Mar Biol Ecol 118:269-279

Fretter V, Graham A (1962) British prosobranch molluscs; their functional anatomy and ecology. Ray Society, London

Haure J, Baud JP (1995) Approche de la capacité trophique dans un bassin ostréicole (Baie de Bourgneuf). Rapport Direction des Resources Vivantes de l'IFREMER. RIDVR95-96/RA-BOUIN, IFREMER, Nantes

Hawkins AJS, Smith RFM, Bayne BL, Héral M (1996) Novel observations underlying the fast growth of suspensionfeeding shellfish in turbid environments: Mytilus edulis. Mar Ecol Prog Ser 131:179-190

Hawkins AJS, Smith RFM, Tan SH, Yasin ZB (1998) Suspension-feeding behaviour in tropical bivalve molluscs: Perna viridis, Crassostrea belcheri, Crassostrea iradelei, Saccostrea cucculata and Pinctada margarifera. Mar Ecol Prog Ser 166:173-185

Iglesias JIP, Urrutia MB, Navarro E, Ibarrola I (1998) Measuring feeding and absorption in suspension-feeding bivalves: an appraisal of the biodeposition method. J Exp Mar Biol Ecol 219:71-86

Johnson JK (1972) Effect of turbidity on the rate of filtration and growth of the slipper limpet, Crepidula fornicata Lamarck, 1799. Veliger 14:315-320

Jørgensen CB, Kiørboe T, Møhlenberg F, Riisgard HU (1984) Ciliary and mucus-net filter feeding, with special reference to fluid mechanical characteristics. Mar Ecol Prog Ser 15:283-292

Kiørboe T, Møhlenberg F (1981) Particle selection in suspension-feeding bivalves. Mar Ecol Prog Ser 5:291-296

La Barbera M (1978) Particle capture by a Pacific brittle star: experimental test of the aerosol suspension feeding model. Science 201:1147-1149

Le Gall P (1980) Etude expérimentale de l'association en chaîne et de son influence sur la croissance et la sexualité chez la crépidule Crepidula fornicata Linné 1758 (mollusque mésogastéropode). PhD thesis, University of Caen

Marteil L (1965) Extension de l'aire géographique de Crepidula fornicata L. pendánt l'année 1964. Sci Pêche Bull Inform Doc Inst Pêches Marit 121:1-6

Méléder V, Launeau P, Barillé L, Rincé Y (2003) Cartographie des peuplements du microphytobenthos par télédétection spatiale visible-infrarouge dans un écosystème conchylicole. CR Acad Sci Biol 326:377-389

Navarro JM, Chaparro OR (2002) Grazing-filtration as feeding mechanisms in motile specimens of Crepidula fecunda (Gastropoda: Calyptreaidae). J Exp Mar Biol Ecol 270: $111-122$

Navarro JM, Widdows J (1997) Feeding physiology of Cerastoderma edule in response to a wide range of seston concentrations. Mar Ecol Prog Ser 152:175-186

Newell RC, Kofoed LH (1977) The energetics of suspensionfeeding in the gastropod Crepidula fornicata L. J Mar Biol Assoc UK 57:161-180

Newell RIE, Jordan SJ (1983) Preferential ingestion of organic material by the American oyster Crassostrea virginica. Mar Ecol Prog Ser 13:47-53

Palmer RE, Williams RE (1980) Effect of particle concentration on filtration efficiency of the bay scallop Agropecten irradians and the oyster Crassostrea virginica. Ophelia 19: 163-174

Ragueneau O, Chauvaud L, Leynaert A, Thouzeau G and 8 others (2002) Direct evidence of a biologically active coastal silicate pump: Ecological implications. Limnol Oceanogr 47:1849-1854

Riera P, Stal LJ, Nieuwenhuize J (2002) $\delta^{13} \mathrm{C}$ versus $\delta^{15} \mathrm{~N}$ of co-occuring molluscs within a community dominated by Crassostrea gigas and Crepidula fornicata (Oosterschelde, The Netherlands). Mar Ecol Prog Ser 240: 291-295

Riisgård HU (1977) On measurements of the filtration rates of suspension feeding bivalves in a flow system. Ophelia 16: $167-173$

Riisgård HU (2001) On measurement of filtration rate in bivalves-the stony road to reliable data, review and interpretation. Mar Ecol Prog Ser 211:275-291

Shumway SE, Frank DM, Ewart LM, Ward JE (2003) Effect of yellow loess on clearance rate in seven species of benthic, filter-feeding invertebrates. Aquat Res 34:1391-1402

Sokal RR, Rohlf FJ (1995) Biometry: the principles and practice of statistics in biological research, 3rd edn. WH Freeman, New York

Sornin JM, Deslous-Paoli JM, Hesse O (1988) Experimental study of the filtration of clays by the oyster Crassostrea gigas (Thunberg): adjustment of particle size for best retention. Aquaculture 69:355-366 
Thieltges DW, Strasser M, Reise K (2003) The American slipper limpet Crepidula fornicata (L.) in the northern Wadden Sea 70 years after its introduction. Helgol Mar Resour 57:27-33

Thieltges DW, Strasser M, van Beusekom JEE, Reise K (2004) Too cold to prosper-winter mortality prevents population increase of the introduced American slipper limpet Crepidula fornicata in northern Europe. J Exp Mar Biol Ecol 311:375-391

Urrutia MB, Iglesias JIP, Navarro E, Prou J (1996) Feeding and absorption in Cerastoderma edule under environmental conditions in the bay of Marennes-Oléron (W. France). J Mar Biol Assoc UK 76:431-450

Walne PR (1956) The biology and distribution of the slipper limpet Crepidula fornicata in Essex rivers. Fish Invest II 20:1-50

Editorial responsibility: Otto Kinne (Editor-in-Chief), Oldendorf/Luhe, Germany
Ward JE, Levinton JS, Shumway SE, Cucci T (1998) Particle sorting in bivalves: in vivo determination of the pallial organs of selection. Mar Biol 131:283-292

Werner VB (1951) Über die Bedeutung der Wasserstromerzeugung und Wasserstromfiltration für die Nahrungsaufnahme der ortsgebundenen Meeresschnecke Crepidula fornicata L. (Gastropoda Prosobranchia). Zool Anz 146:97-113

Widdows J, Fieth P, Worrall CM (1979) Relationship between seston, available food and feeding activity in the common mussel Mytilus edulis. Mar Biol 50:195-207

Wilczynski JZ (1958) On sex behaviour and sex determination in Crepidula fornicata. L. Publ Univ Libanaise Sect Sci Nat IV:5-53

Williams LG (1982) Mathematical analysis of the effect of particle retention efficiency on determination of filtration rate. Mar Biol 66:171-177

Submitted: July 19, 2005; Accepted: March 16, 2006 Proofs received from author(s): September 6, 2006 